\title{
LEARNING HISTORY FOR CURRICULUM DEVELOPMENT WITH DIGITAL LEARNING MEDIA IN THE 21ST CENTURY
}

\author{
Cindy Andhika Sari ${ }^{1}$, Moses Glorino Rumambo Pandin ${ }^{2}$ \\ Faculty of Humanities, Airlangga University \\ Email: cindy.andhika.sari-2020@ fib.unair.ac.id and moses.glorino@ fib.unair.ac.id
}

\begin{abstract}
Education is a crucial aspect of survival. Education is a system consisting of several components that can influence and determine. In the education field, history needs to be taught to introduce humanities, space, society, and the relation between the present and the past. In the globalization era, to make a good education, there should be an innovation, such as digital media, to create the curriculum. The method used in the study is the qualitative description and literature review from 20 journal articles with publication years in 2019-2021. The result of the study is that the high school student's interest in learning history is still reduced because of the learning media. Based on the results obtained, it is expected to provide information about learning history for curriculum development with digital media in the 21 st century. This research was conducted at SMA Wachid Hasyim 5 Surabaya using data collection techniques through observation and interview. This study aims to provide the latest innovations in historical learning in the 21 st century based on existing problems. The researcher focuses on how teachers can apply digital learning methods to students in the 21 st century to become better in the future. The development of science and technology in the 21 st century is overgrowing to provide a positive supply to students. Several recommendations can be submitted related to improving motivation and learning outcomes of history through digital media learning models. This advice is intended for interested parties in education: the Ministry of Education and Teachers. The research has limitations, which are limited to curriculum development on learning history with digital media in the 21 st century.
\end{abstract}

Keywords: 21st Century, Learning Innovation, Curriculum, Education 


\section{INTRODUCTION}

The context of this historical learning model is far from relevant to today's lives. From elementary school to high school, history learning tends to use historical facts as the main ingredient. It is no stranger that historical education feels dry, unattractive, and does not allow students to learn to explore the meaning of historical events. Strategic assessment with the pedagogical history of Indonesia is very weak. Historical education in schools still struggles with a chronic approach and requires students to memorize an event. Students are not used to interpreting an event to understand the dynamics of change.

This problem is significant to be examined because the historical learning methods suitable for making students and teachers act as facilitators are constructivism, research, and cooperative learning. Constructivity is that knowledge is built by man little by little; the result is expanded through limited context. The study of the history of constructive related to learning and problems faced by students in their daily lives. The request method is also similar to historical education. However, the knowledge and skills gained are expected not to remember a series of facts but to find themselves. Finally, the use of cooperative learning models such as digital learning media has put teachers as facilitators.

The development of education in the 21 st century is different from the development of education in the previous century (1). Today, technology plays an essential role in the advancement and development of learning activities. The 21 st century is a condition that can be characterized by rapid development in terms of information and communication technology such as laptops, computers, mobile phones, and others, even as technology is getting faster and faster, making the Internet experience tremendous development. With more and more use of the internet or blogs, the 21st-century generation should understand the technology and development of the internet. The case in every educational institution that developed in the $21 \mathrm{st}$ century demands students' intelligence and other skills and abilities that require competence now (2). As evidenced by the number of learning methods in schools, students use learning strategies and more varied techniques and innovations (3).

The demands of competence in the 21st century that are inseparable from the existing curriculum will constantly evolve. This can be done with the qualitative description theory of e-learning because it describes effective multimedia learning science principles using electronic educational technology. In addition, the researcher focuses on the question of how teachers can apply digital learning methods to students in the 21 st century so that the academic 
curriculum becomes better in the future. The results of research and theory show that the selection of appropriate multimedia modalities will create learning (4). On the other hand, curriculum development is demanded by the creativity and innovation of teachers in teaching because a good education is learning that can make students get something new. Therefore, the curriculum needs to be evaluated and developed according to the current demands. Thus, curriculum development is inseparable from how the educational component runs, ranging from objectives, content, materials, methods, activities, and assessments, all interconnected with each other to achieve good curriculum development by the demands of 21 st-century competencies.

The educators need to develop students' skills in learning to survive in work and be ready to compete with other countries. Therefore, teachers prepare all kinds of curriculum, learning plans, models, or methods for the 21st century (5). By developing 21st-century education, it is expected that the individual can live in the 21 st century full of opportunities and challenges, and also in the future. Therefore, some experts explain the importance of mastering 21 st-century skills to succeed in a century where the world is developing fast and dynamic (6).

The development of science has to face the demands of competence of the 21 st century where the needs are no longer the same as the past demands. This article aims to examine the global outlook in curriculum development and the role of teachers in facing the demands of growth in this century, and the needs of curriculum development competencies (7). In achieving the learning objectives, it takes the concept of learning model relevant in learning activities. Model learning is everything done during the learning class process by the procedures determined to achieve results in the learning process. In the 21 st century, people use various learning models for history studies programs (8). The learning model itself is digital media in the learning process to provide knowledge for students about the influence of learning models in history.

\section{RESEARCH METHODS}

The research uses qualitative description methods with literature review or library review and based on observations in the education world that are often a problem for educators in teaching. The observation method is expected to be an understanding for educators in the 21 st century. Then, the research materials are obtained from various relevant sources such as journals, official websites, and data reports. 
The data sources used are from the Central Bureau of Statistics or Badan Pusat Statistik in Indonesian (BPS). Besides, this article used the data based on observation and various reference sources such as relevant journals taken from google scholar and data report that has specific criteria: 1. Journal articles with a minimum number range of 10-20 pieces, 2. Journal articles with a range of years between 2019-2021,3. Articles published in validated journals, 4. Data reports are taken from validated websites and relevant to research.

In data analysis, the researcher refers to data analysis in four stages. Those are presented below.

\section{Data collection}

Data collection, as mentioned, is done through the literature review method or library review on several sources of journal article source articles and data reports.

2. Data reduction

Data reduction is the process of selecting, simplifying, and abstracting the collected data. The first process is to summarize the findings in the researchers' research journal article, select the main points from the summary results, focus on the crucial things to find specific themes and patterns on the data findings, and remove or select unnecessary ones.

3. Data presentation

Data presentation is data that has been reduced and has been selected and can be presented in a coherent way, resulting in composed information. The data analysis presentation uses narratives and tables because research data with qualitative methods are more dominant in descriptions, thus requiring simplification without reducing the content.

4. Conclusion withdrawal and data verification

After going through the above stages, the research data is ready to be concluded and verified by looking and questioning again, thus gaining a more precise understanding. The verification process of the interim conclusion can be done by repeating the research steps by retracting all the research steps that have been done, including the examination of data collected from the field. Reductions are made based on research records and provisional conclusions that have been formulated (9).

The research uses journal articles as a reference. The article contains research that has been done by experts so that this journal article can be ascertained the truth. In addition, it is 
also strengthened by other sources such as official and trusted websites. This data collection technique uses library studies in journals, data reports with specific criteria, and observations. Observation is a research technique looking at human behavior, work processes, and natural symptoms observed in a small scope. Through observational studies conducted by the researchers, it is known that there are still many educators who have not utilized learning media in the 21 st century.

So, the learning process conducted by teachers is still using many old methods, so many students are less interested in history lessons. Therefore, the researcher wants to introduce innovative media that suits students' development to keep them motivated to know more about history lessons. Furthermore, the researcher will also conduct interviews with teachers on historical learning issues to obtain documentation of students, such as curriculum, RPP, and the value of learning outcomes.

\section{RESULT}

The research uses a literature review from 20 relevant journals published in 2019-2021. Reference retrieval can be referenced through publication presentations through the website as well as reports related to research. The details of the year of publication of the article are in the publication in 2021, four journals on developing education and improving learning outcomes. Meanwhile, the journal on the influence of learning models in the 21st century, published in 2020, is eight in total, and in 2019 are eight journals on the development of learning media. Besides, there is a website in 2020, and data report in 2020 there are 2 data. These journals result from previous research and have passed the data interpretation step so that the referenced journal has fulfilled and completed the theme raised from this article.

In addition, the study used other more credible sources such as the official website of the relevant institute and data reports. For example, one website from the relevant institutions in 2020 explains the development of the curriculum in Indonesia. This study also obtained a data report from the Central Bureau of Statistics (BPS) on the graph of interest in learning history from 2021. Thus, the total body of this research amounted to 22 reference sources.

Overall, the results of the data analysis from the literature review showed that the historical studies to develop a curriculum with digital learning media in the 21 st century had shown relevance to students' interest in the subjects of history and the way of learning. But 
after being observed, the analysis results cover various aspects, so the data in the study is collected and then interpreted.

\section{DISCUSSION}

Based on the research results, the researcher uses qualitative to describes e-learning theory. E-learning is an educational system that uses electronic applications to support teaching and learning using internet media or computer networks. To see the usefulness of e-learning by teachers as a medium of education, in-depth studies need to be done. E-learning media has drawbacks and advantages that are not limited to space and time; learning materials are also easy to obtain, lack direct social interaction, and students tend to be lazy with the benefits of elearning.

The results of research and theory show that the selection of appropriate multimedia modalities will create learning. But, on the other hand, curriculum development is demanded by the creativity and innovation of teachers in teaching because a good education is learning that can make students get something new. Therefore, the curriculum needs to be evaluated and developed according to the current demands. Therefore, curriculum development is inseparable from how the educational component runs, ranging from objectives, content, materials, methods, activities, and assessments, all interconnected with each other to achieve good curriculum development by the demands of 21 st-century competencies.

\section{Learning Development in the 21st century}

The process of relations between countries is a phenomenon that marks the era of globalization. It happens without a hub between social and national boundaries ideologically. As the whole world forms itself as one and participates in globalization, this dependence occurs not only in science, technology, and the arts (science and technology) but also in economic, social, and cultural politics, including in the field of education. It has a dependency associated with the role of the teacher. It becomes a means to produce creativity, value, and success with high power to improve abilities.

In the 21 st century, the development of education was speedy. Students are required to face various risks, ranging from technology, culture, and the development of scientific knowledge. The aims are to make students learn more and to be active in the learning process to have adequate knowledge. The learning of the 21st century is different and much more 
complicated than the life of the previous era. Therefore, swords are suitable for teachers in their role as educators in learning to the worshiper, required to provide knowledge, behavioral attitude skills through strategy and method lessons by the development of the 21 st century. Thus, all the responsibilities of education he entrusted to the teacher, especially give conditions that can prepare students for the global time.

Therefore, we need a solution to improve the current generation, especially students, to be more interested in learning history. Moreover, judging from the current situation of technological progress developing very rapidly such as curriculum, curriculum containing global insight is a curriculum that is a global perspective, in the public domain that is not national. Therefore, the curriculum should indirectly encourage students to think critically. Then, the knowledge as much as possible can be applied as a helpful citizen readiness and form a sense of social responsibility for the environment, working together and holding on to each other harmoniously.

\section{Results of Student Motivation towards Learning History}

Interview results related to students of 20 students with different classes showed 10 unmotivated children with a percentage of $50 \%$, less motivated students showed 5 children with a presentation of $25 \%$, students who were motivated as many as 5 children with a percentage of $25 \%$ to the learning process of history. This shows that the learning process in history lessons that have been done in school is less motivating for students.

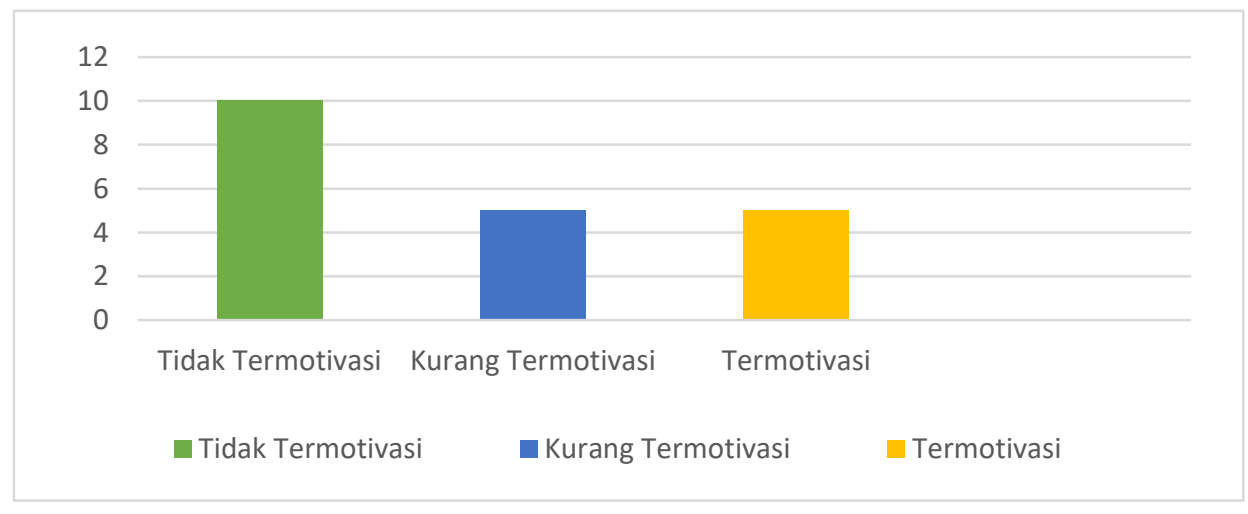

Figure 1. Percentage of Motivation of Students in Learning History

Source : ejournal.staidarussalamlampung.ac.id

Identification of interview results to students with 20 students showed that history teachers' application of learning methods had been less in students' interest. As many as 10 children with $50 \%$ stated that they were not motivated by learning history. In comparison, as 
many as 5 children with presentations $25 \%$ were less motivated by the method of historical science. Only as many as 5 children with presentations $25 \%$ were motivated by the method of learning history. Based on the data above, teachers' learning history in high school is not maximal. Many students are less motivated, even not motivated by the learning of history.

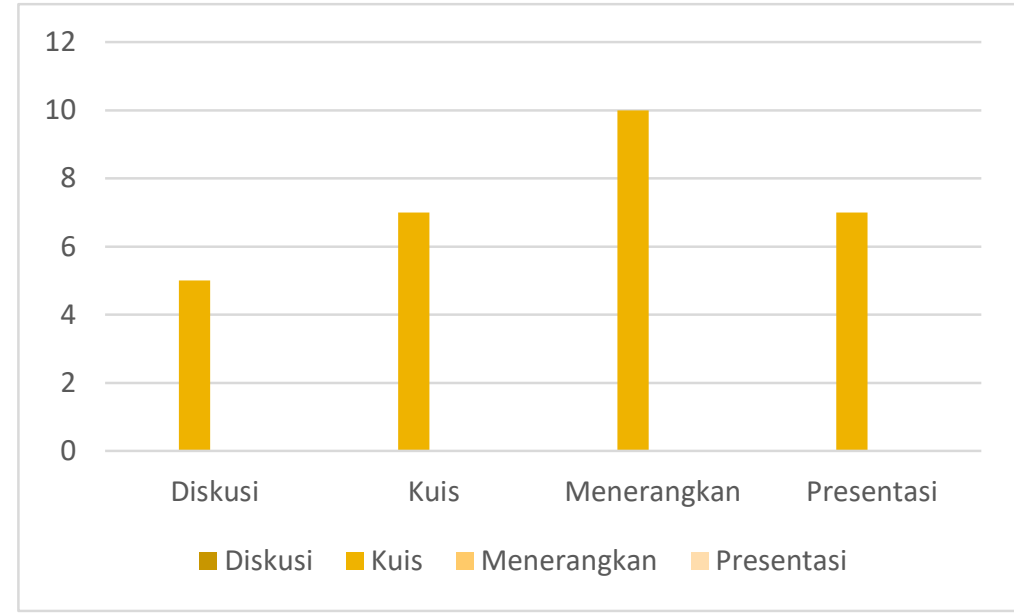

Figure 2. Methods Teachers Often Use in the Learning Process

Source : jurnal.kurasinstitute.com

Looking at the data above, we can see also that the learning methods carried out by teachers still actually use the old techniques that are not very maximal and are not also supported by the curriculum and learning in the 20th century. Such learning methods are very unable to attract students in the study of history. Therefore, a teacher must provide many new and creative learning methods that can stimulate students' interest in learning history. A good and fun teaching and learning activity process can be achieved by the development of today's times.

\section{Types of Media that Teachers Should Apply in The Learning Process of History}

Based on the data results that the researcher can from interviewing students, many teachers are still using learning media using LKS, explaining in the classroom, quizzes, discussions, and presentation media (10). This causes students to lack understanding of historical science learning materials because learning history science that only uses printed book media or presentations is less effective in motivating students' interest in learning history. This should be considered more by history teachers to find engaging and interactive learning media that can facilitate material delivery, so that history learning is more exciting and meaningful (11). 
Furthermore, digital learning media will create innovations to generate new creativity in learning and solve problems with new methods. Innovation is an idea, an item, an event, a method that is perceived or observed as unique to a person or group of people (community), either discovery or discussion (12). Innovation has a specific goal that is to solve problems or achieve certain goals

The Ministry of Education and Culture (Kemendikbud) strives to continuously conduct education equality throughout Indonesia and the development of technology to make it easier for students to access prison materials. Furthermore, the plans to develop education quality are needed to change the learning pattern to be better so that students get alternative learning materials obtained from teachers and books but can be from various sources (13).

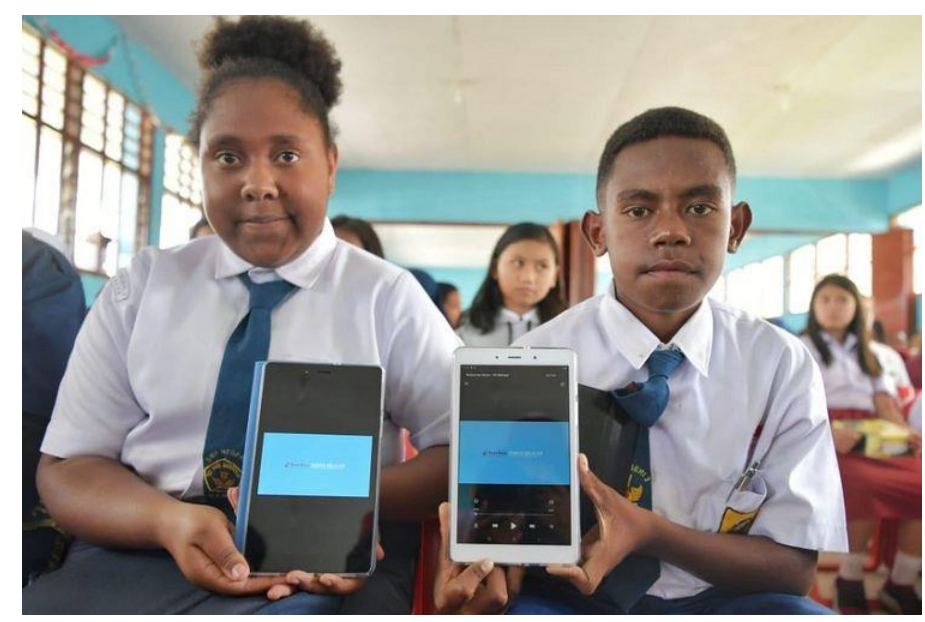

Figure 3. Illustration of Digital Media Learning in Papua Province Source : edukasi.kompas

The illustration of the picture above is an example of digital learning that the researcher wants to be able to apply in the 21 st century, so it is expected that students can continue to develop as a generation that has enough ability to anticipate the educational revolution in the era of globalization (14). Furthermore, this digital learning method is done so that students in remote areas of Indonesia are not outdated and can follow a rapidly growing curriculum development. Therefore, this digital learning model is very effectively used as a model of 21 stcentury learning. Thus, using digital models will be achieved with the planned components of historical science material.

The purpose of the application of digital learning as a model of learning in the $21 \mathrm{st}$ century is to improve the curriculum and improve the ability of students' sense of responsibility related to the material to be discovered by the process of learning activities that are very enjoyable in the learning of history (15). Therefore we must understand the characteristics of students before using learning media in teaching activities. Furthermore, the implementation 
of the learning model must be by the competency approach to improve the results of achievements in using digital media in schools (16).

\section{Students' Responses to Digital Media in Historical Science Learning}

Based on the results of interviews of students with the number of 20 children to digital media, among others 2 students do not agree with the percentage of $10 \%$, as many as 2 children answered less agree with the presentation 10\%, 4 students answered agreed with a percentage of $20 \%$. As many as 12 students responded strongly blended with the percentage of $60 \%$ (17).

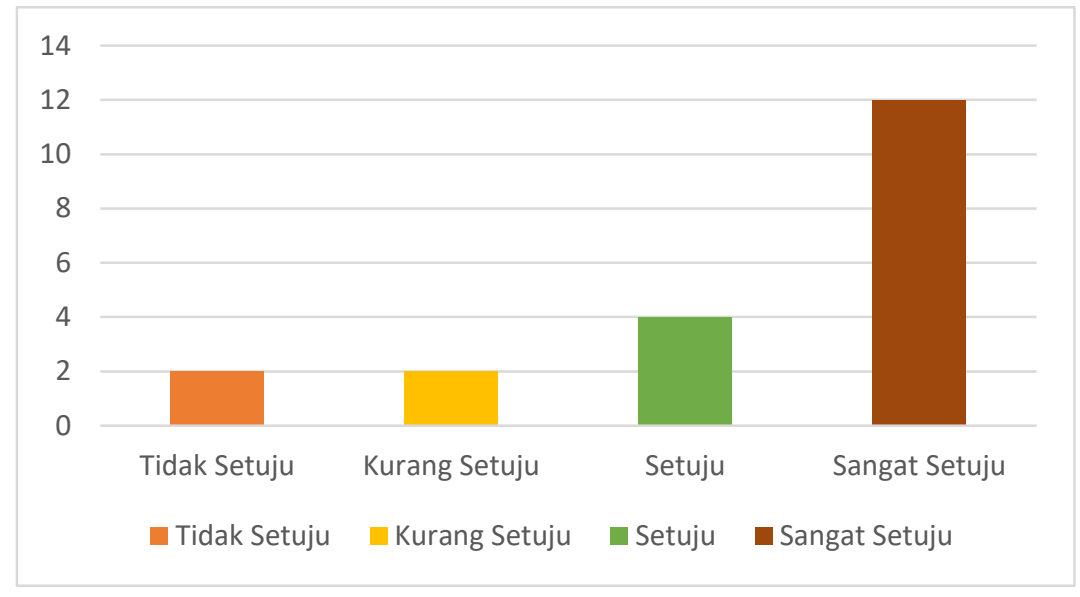

Figure 4. Students' Responses to Digital Media in Historical Science Learning

Source : jurnal.fkip

The use of digital media can provide more meaningful learning if used in the study of history to be more motivating for participants in understanding history lessons. In addition, digital media designed and combining audio, video, animation, text, and others can improve students' critical thinking skills in the study of history (18). However, the development of digital media is based on the needs of students because considering it is still very minimal in history subjects at the high school level (19).

The results of interviews from teachers in schools are LKS books, quizzes, and presentations with PowerPoint media, are often used and are already available in schools. In addition, teachers' skills are still limited in developing innovative digital media. Teachers still use learning methods that seem monotonous with discussion methods, explaining in the classroom, and presentations in learning history. This impacts the lack of motivation and understanding of the subject matter of the history of the students. So, it was found that the average competency value of historical science subjects is still below the minimum score 75 , which is 65 . 
Historical science learning needs to adapt to today's digital age by developing innovative learning media. One solution in answering learning history is to establish learning media so that the learning of history is more exciting and meaningful. Based on this, innovative education using digital media for students and teachers in high school is needed to improve students' motivation and learn outcomes in history subjects (20).

The development of digital media is a solution to the needs of the learning process. The application of digital media causes this problem to create an effective and efficient learning process, so teachers are expected to be creative and innovative in creating a learning process that can combine text, images, audio, and video in one unit to achieve the learning objectives of history. In addition, the learning process will provide more motivation for students because it can visualize material that is difficult to explain with conventional media and train students to be more independent in gaining knowledge without always being guided by the teacher so that the learning objectives are expected (21). Digital development as a learning medium is scheduled to make teachers and students more accessible to improve the results of interest and learning outcomes in the learning process of history science (22).

\section{CONCLUSION}

Based on the discussion results, the role of teachers in applying digital learning methods to students in the 21 st century, so that the educational curriculum becomes better in the future is to motivate students in the process of learning history by developing historical learning. Based on the researcher's interviews with several students in school, many students are not encouraged to study history. In addition, the low learning outcomes of students are still very lacking even under KKM 75, which is 65 , so that students and teachers are very much expecting solutions in addressing curriculum problems and historical learning methods that occur. The development of digital media can be one way to overcome these problems so that the motivation and interest of students in learning history can increase (23).

The results of interviews with teachers of history subjects at Wachid Hasyim 5 High School teachers expect the latest innovations in the learning of history to improve student's learning outcomes. The teaching of history in the digital era. So, that teacher is expected to be 
more creative and innovative in delivering history lessons. As students in the 21 st century we must also be able to think creatively and innovatively, students must also understand digital literacy, which is a new method in digital-based learning to support the learning of history in the 21 st century.

The limitation or limitation of this study lies in the research process. Researchers realized that in the study, there were many obstacles and resistances. One of the factors that are obstacles in this study is the time and place of research. The field used for history learning is Wednesday and Friday, and the learning time is 08.00-09.30. Because of the limited time and place of research, the researchers engaged the teacher to conduct learning in the conventional group so that students in the convention group gained significant understanding.

Several recommendations can be submitted related to improving motivation and learning outcomes of history through digital media learning models. This advice is intended for interested parties in education, namely: the Ministry of Education and Teachers. Some of these recommendations are as follows:

1. Ministry of Education

Ministry of Education Surabaya to work with relevant institutions to use the findings of this research by disseminating it to teachers through improvement or training. So they have the knowledge and ability to apply learning models to be used in the learning process.

2. Teachers

For teachers who apply digital media as a learning process should be done in their respective classrooms. Using digital media models, teachers should make better and more mature preparations, especially in preparing clear and structured materials to understand them easily. 


\section{REFERENCES}

1. Abdillah Karim HT. Pengembangan Kurikulum Menghadapi Tuntutan Kompetensi Abad Ke 21 Di Indonesia. lonsuit.unismuhluwuk. 2020;Vol 4 No.1:20.

2. Afriza Zelfi. Perkembangan Media Pembelajaran Berbasis Aplikasi Android Menggunakan Appy Pie Materi Perang Dunia Dan Kelembagaan Dunia Siswa Kelas XI SMA PGRI 2 Kota Jambi. repository. 2019;15.

3. Andrian Jati Wasiso SMW. Pengaruh model pembelajaran dan sikap sosial terhadap hasil belajar Sejarah SMA Negeri 24 Kabupaten Tangerang. journal.uny.ac.id. 2020;Vol 13 No.:10.

4. Aries EP. Meningkatkan Hasil Pembelajaran Online Sejarah Berbasis Media Presentasi Interaktif. ahlimedia.jurnal. 2021;Vol 2 No.5:12.

5. Arifin Zainal M SA. Strategi Belajar dan Mengajar Guru Pada Abad 21. jurnal.kurasinstitute.com. 2020;Vol 1 No.2:10.

6. Dewi Ruslama Diah. Pengembangan Kurikulum Di Indonesia Dalam Menghadapi Tuntutan Abad Ke-21. e.journal.staidarussalamlampung [Internet]. 2019;Vol. VIII:22. Available from: http://ejournal.staidarussalamlampung.ac.id/index.php/assalam/article/view/123/182

7. Dina insani Farah. Sejarah Perkembangan Kurikulum Di Indonesia Sejak Awal Kemerdekaan Hingga Saat Ini. e.journal.staidarussalamlampung. 2019;Vol 8 No.1:22.

8. Farrah C. Analisis Landasan Ilmu Pengetahuan dan Teknologi dalam Pengembangan Kurikulum. journal.lppmunindra. 2020;Vol 5 No.:9.

9. Miftah Rezkia Salsabila. Langkah-Langkah Menggunakan Teknik Analisis Data Kualitatif. dqlab.id. 2020;Vol 9.

10. Hutapea Erwin. Tantangan Digitalisasi Sekolah Di Papua, Perhatikan Dua Faktor Ini. edukasi.kompas. 2019;10.

11. Iftina D. Perkembangan Pendidikan di Era Globalisasi. jurnal.unibrah.ac.id. 2021;Vol 7 No.2:8

12. Kurniawan Syamsul. Tantangan Abad 21 bagi Madrasah di Indonesia. jurnal.radenfatah [Internet]. 2019;Vol 25 No.:68. Available from: 
http://jurnal.radenfatah.ac.id/index.php/intizar/article/view/3242

13. Muhali. Pembelajaran Inovatif Abad Ke-21. journal.center.litpam.com. 2019; Vol 3 No $2: 26$.

14. Muhtaram Herdin KD. Pengaruh Model Pembelajaran Abad 21 Terhadap Pembelajaran Sejarah Eropa. jurnal.unsil.ac.id. 2020;Vol 3 No.2:7.

15. Nugraha Yogi, Sapriya, Danial Endang R. Kurikulum Program Studi Pendidikan Pancasila dan Kewarganegaraan Berbasis Digital di Era Revolusi Industri 4.0. journal.ubpkarawang. 2020; Vol 5 No.1:15.

16. Nusafitri Eka, Anis Ahmad Alex AKSO. Pengaruh Model Pembelajaran Kooperatif Tipe Complex Instruction Terhadap Hasil Belajar Siswa Pada Mata Pelajaran Sejarah Indonesia. Jurnal.unsil.ac.id. 2020;Vol 3 No.1:11.

17. Piki SP. Desain Skenario Pembelajaran Aktif Dengan Metode "Mikir" Pada Mata Kuliah Pendidikan IPS. ejournal.iainbengkulu. 2019;Vol 1 No.2:11.

18. Sumarno. Pembelajaran Kompetensi Abad 21 Menghadapi Era Society 5.0. ojs.semdikjar.fkip. 2019;Vol 3:16.

19. Susilo Agus SA. Sejarah dalam Pemanfaatan Inovasi Media Pembelajaran. journal.univetbantara. 2020; Vol 4 No 2:15.

20. Suwandi Sarwiji. Implementasi Pembelajaran Abad Ke 21 Dan Tantanganya Untuk Berperan Dalam Masyarakat 5.0. jurnail.univpgri. 2020;15.

21. Syahputra Een. Pembelajaran Sejarah di Abab 21 (Telaah Teoritis terhadap Model dan Materi). jurnal.fkip. 2019; Vol 3 No.1:10.

22. Putra Adyatama Rama. Peran Guru dalam Inovasi dan Teknologi Pendidikan di Abad 21. osf.io. 2021;

23. Ikhzarullah Muhammad. Pembelajaran Sejarah Berbasis Online, Media Digital Pembelajaran Sejarah, dan Kreatifitas Guru. osf.io. 2021; 
Tabel Attachment

\begin{tabular}{|c|c|c|c|c|}
\hline No. & Category & Years (2019-2021) & Amount & $\begin{array}{c}\text { Percentage in the } \\
\text { literature review }\end{array}$ \\
\hline 1 & Journal Articles & 2019 & 8 & $34,72 \%$ \\
\hline 2 & Journal Articles & 2020 & 8 & $34,72 \%$ \\
\hline 3 & Journal Articles & 2021 & 4 & $17,39 \%$ \\
\hline 4 & Situs Website & 2019 & 1 & $4,34 \%$ \\
\hline 5 & Data Report & 2020 & 2 & $8,69 \%$ \\
\hline
\end{tabular}

